\title{
A Glossary of Terms
}

anti-maidan: a loosely associated collection of social movements that were generally characterized by a pro-Russian or anti-European politics and organized in opposition to the EuroMaidan revolution and the political changes it triggered.

baiduzhist: (Ukrainian) indifference.

bazhannia: (Ukrainian) desire.

Berkut: a special police force operated under the aegis of the Ukrainian Ministry of Internal Affairs, whose duties included the preservation of civil order within the sovereign territory of Ukraine. The Berkut was disbanded by an order of Ukrainian parliament in 2014.

Donbas: a region of eastern Ukraine that includes territories around the Donets'k River. Donbas is a shortening of Donets'k Basin.

EuroMaidan: a large antigovernment protest movement that originated in Kyiv in November 2013, but spread to many different cities in 
Ukraine in the following months. The protests ended in the deaths of more than one hundred civilians due to police violence and the flight of President Viktor Yanukovych from Ukrainian territory.

gosudarstvo: (Russian) sovereign.

khoziaistvo: (Russian) domain.

narcology: a medical specialization recognized in Soviet medicine concerned with the prevention and treatment of "addictive" disorders.

narkoman: (Russian/Ukrainian) someone who uses drugs.

opiate: any pharmacological substance derived from opium, a latex excretion of the opium poppy. Codeine, morphine, and heroin (diacetylmorphine) are examples of natural opiates.

opioid: a term used to describe any pharmacological substance, whether natural or synthetic, which binds to opioid receptors in the brain. Methadone, fentanyl, and buprenorphine are examples of synthetic opioids.

ravnodushie: (Russian) indifference.

shirka: (Russian/Ukrainian) a slang term that refers to an opiate solution derived from poppy plants, which is commonly injected in Ukraine. svoi: (Russian/Ukrainian) ours, our own. zhelanie: (Russian) desire. 